\title{
ОСОБЛИВОСТІ КЛІНІКИ ТА ПЕРЕБІГУ ЗАКРИТОЇ ЧЕРЕПНО-МОЗКОВОЇ ТРАВМИ ЛЕГКОГО СТУПЕНЯ ТЯЖКОСТІ У ВОЯКІВ АНТИТЕРОРИСТИЧНОЇ ОПЕРАЦЇ̈ У ВІДДАЛЕНОМУ ПЕРІОДІ
}

\author{
ПАТ "Укрзалізниця", Львівська клінічна лікарня на залізничному транспорті ${ }^{1}$, \\ Львівський національний медичний університет імені Данила Галицького 2
}

\begin{abstract}
Резюме. Стаття присвячена вивченню психопатологічної симптоматики за допомогою опитувальника DEROGATIS у бійців антитерористичної операції (ATO) при закритій черепно-мозковій травмі (ЗЧМТ) легкого ступеня тяжкості у віддаленому періоді [2, 3, 6, 13]. Виявлена виразність психопатологічної симптоматики в групах обстежених нами бійців за всіма шкалами дослідження була достовірно вищою за контрольну
\end{abstract}

Вступ. Останні три десятиліття історії нашої держави були насичені драматичними, екстремальними за своєю силою подіями. Змінювались соціально-економічні формації, руйнувались ідеологічні системи, відбувалися техногенні (аварія на Чорнобильській АЕC) та природні катастрофи [16]. Сучасні трагічні події (бойові дії в зоні АТО) призвели до великої кількості загиблих і поранених, а також осіб, котрі змушені залишати свої домівки і ставати біженцями $[10,12]$. Бойові діï, терористичні акти і насилля проти особистості мають психотравмуючий вплив на психічне здоров'я людини та якість ії життя $[9,11]$.

Бойова черепно-мозкова травма виникає в потерпілих під час бойових дій і включає в себе всю сукупність травм і поранень. Вогнепальні поранення черепа і головного мозку під час Великої Вітчизняної війни становили 5,2-7,0 \%, а під час ведення бойових дій у локальних конфліктах сьогодення частота поранень черепа і головного мозку значно зросла і сягає 16,0-59,0 \%. Загальна летальність при легкій черепно-мозковій травмі становить 4,0-17,0 \%, а при тяжкій 70,0 \%. Інвалідами стають 19,0 \% потерпілих, а зниження працездатності відмічається у 47,0-51,0 \% потерпілих, переважно це особи молодого і середнього віку. 3 урахуванням цих даних травма черепа і головного мозку посідає перше місце серед захворювань, випереджаючи серцево-судинні захворювання і онкопатологію [4, 14]. Останніми роками різко зросла кількість вогнепальних поранень у мирний час. Діагностика їх грунтується на даних неврологічного, оториноларингологічного, нейроофтальмологічного, доплерографічного, лабораторного, рентгенологічного (комп'ютерна томографія, магнітно - резонансна томографія, рентгенографія черепа, нейросонографія) досліджень $[1,3,7,8,15]$.

Мета дослідження. Вивчити психопатологічні наслідки ЗЧМТ легкого ступеня тяжкості у бійців АТО у віддаленому періоді.

Матеріал і методи. Всього в обстеженні брали участь 100 бійців АТО з різними психопа- групу. Подальше вивчення змін у психологічній сфері у віддаленому періоді ЗЧМТ у вояків АТО ставить питання про створення спеціалізованих реабілітаційних центрів для проведення в них соціально-відновної реабілітації таких хворих [5].

Ключові слова: ЗЧМТ, віддалений період, АТО, психопатологічні наслідки.

тологічними наслідками перенесеної травми черепа і головного мозку в терміні один рік після травми. Із них 61 вояк був із струсом головного мозку (СГМ) та 39 вояків із забоєм головного мозку легкого ступеня (ЗГМЛС). Контрольну групу склали добровольці в кількості 73 осіб, які до служби в АТО перенесли ЗЧМТ легкого ступеня тяжкості. Ефективний метод визначення психопатологічної симптоматики при допомозі опитувальника DEROGATIS ми застосували для діагностики функціонального стану мозку у вояків АТО з різними наслідками травми для розроблення нових підходів до лікування та реабілітації потерпілих у зоні конфлікту під час гібридної війни.

Результати дослідження та їх обговорення. Залежно від клінічної форми перенесеної черепно-мозкової травми і особливостей іiї перебігу на даний час виокремлюють синдром загальномозкових розладів, синдром вогнищевого випадіння функцій мозку, синдром рухових розладів, порушення функцій черепних нервів, синдром стовбурових розладів (при тяжкій травмі).

Струс головного мозку - функціональнозворотна форма ЗЧМТ. 3 усіх потерпілих такі хворі становлять 75,0-80,0 \%. У віддаленому періоді спостерігається нормалізація порушених функцій, але можуть бути лабільні нейродинамічні процеси і хворі скаржаться на загальну слабкість, біль голови різного характеру, біль у м'язах шиї, іпохондричний або депресивний стани.

Забій головного мозку - це вогнищеве ураження мозку, нерідко з внутрішньочерепними крововиливами. Частота забою мозку становить 18,0-49,0 \%, летальність висока (до 80,0 \%). Локалізація - лобово-скроневі, лобово-тім'яні і тім'яні ділянки. Для забою мозку характерне поєднання функціональних і морфологічних змін, які проявляються загальномозковими, вегетативними, вогнищевими і стовбуровими симптомами.

Психопатологічні наслідки ЗЧМТ проявляються у вигляді психоорганічного синдрому i характеризуються підвищеним виснаженням та 
Виразність психопатологічної симптоматики в групах порівняння за шкалами опитувальника DEROGATIS

\begin{tabular}{|c|c|c|c|c|c|c|c|c|}
\hline \multirow{3}{*}{$\begin{array}{l}\text { Шкали опитуваль- } \\
\text { ника DEROGATIS }\end{array}$} & \multicolumn{4}{|c|}{ Середні значення за шкалами (M $\pm \mathrm{m})$, бали } & \multicolumn{4}{|c|}{$\begin{array}{c}\text { Достовірність відмінностей } \\
\text { між групами (p) }\end{array}$} \\
\hline & \multicolumn{3}{|c|}{ Обстежені } & \multirow{2}{*}{$\begin{array}{l}\text { Група конт- } \\
\text { ролю, } \mathrm{n}=73\end{array}$} & \multicolumn{2}{|c|}{$\mathrm{n}=39$ вояків } & \multirow{2}{*}{$\begin{array}{c}\mathrm{n}=61 \\
\text { вояк }\end{array}$} & \multirow{2}{*}{$\begin{array}{c}\mathrm{Bci} \\
\mathrm{n}=100 \\
\text { осіб } \\
\end{array}$} \\
\hline & $\begin{array}{c}\mathrm{n}=39 \\
\text { ЗГМЛС }\end{array}$ & $\begin{array}{l}\mathrm{n}=61 \\
\mathrm{C} \Gamma \mathrm{M}\end{array}$ & $\begin{array}{l}\mathrm{n}=100 \\
\text { Всього }\end{array}$ & & $\mathrm{n}=61$ & & & \\
\hline $\begin{array}{l}\text { Шкала SOM } \\
\text { соматизація }\end{array}$ & $\begin{array}{c}1,26 \pm \\
0,10\end{array}$ & $\begin{array}{c}0,96 \pm \\
0,05\end{array}$ & $\begin{array}{c}1,08 \pm \\
0,04\end{array}$ & $\begin{array}{c}0,50 \pm \\
0,03\end{array}$ & $\begin{array}{c}\mathrm{P}^{1} \\
<0,05\end{array}$ & $\begin{array}{c}\mathrm{P}^{3} \\
<0,001\end{array}$ & $\begin{array}{c}\mathrm{P}^{3} \\
<0,001\end{array}$ & $\begin{array}{c}\mathrm{P}^{3} \\
<0,001\end{array}$ \\
\hline $\begin{array}{c}\text { Шкала ОС } \\
\text { обсесивність - ком- } \\
\text { пульсивність } \\
\end{array}$ & $\begin{array}{c}1,35 \pm \\
0,10\end{array}$ & $\begin{array}{c}1,11 \pm \\
0,05\end{array}$ & $\begin{array}{c}1,20 \pm \\
0,04\end{array}$ & $\begin{array}{c}0,40 \pm \\
0,02\end{array}$ & & $\begin{array}{c}\mathrm{P}^{3} \\
<0,001\end{array}$ & $\begin{array}{c}\mathrm{P}^{3} \\
<0,001\end{array}$ & $\begin{array}{c}\mathrm{P}^{3} \\
<0,001\end{array}$ \\
\hline $\begin{array}{c}\text { Шкала INT } \\
\text { міжособистісна сен- } \\
\text { ситивність }\end{array}$ & $\begin{array}{c}1,32 \pm \\
0,11\end{array}$ & $\begin{array}{c}0,97 \pm \\
0,05\end{array}$ & $\begin{array}{l}1,11 \pm \\
0,05\end{array}$ & $\begin{array}{c}0,40 \pm \\
0,01\end{array}$ & $\begin{array}{c}\mathrm{P}^{1} \\
<0,05\end{array}$ & $\begin{array}{c}\mathrm{P}^{3} \\
<0,001\end{array}$ & $\begin{array}{c}\mathrm{P}^{3} \\
<0,001\end{array}$ & $\begin{array}{c}\mathrm{P}^{3} \\
<0,001\end{array}$ \\
\hline $\begin{array}{l}\text { Шкала DEP } \\
\text { депресія }\end{array}$ & $\begin{array}{c}1,17 \pm \\
0,11\end{array}$ & $\begin{array}{c}0,87 \pm \\
0,05\end{array}$ & $\begin{array}{c}0,99 \pm \\
0,05\end{array}$ & $\begin{array}{c}0,28 \pm \\
0,01\end{array}$ & $\begin{array}{c}\mathrm{P}^{1} \\
<0,05\end{array}$ & $\begin{array}{c}\mathrm{P}^{3} \\
<0,001\end{array}$ & $\begin{array}{c}\mathrm{P}^{3} \\
<0,001\end{array}$ & $\begin{array}{c}\mathrm{P}^{3} \\
<0,001\end{array}$ \\
\hline $\begin{array}{l}\text { Шкала ANX } \\
\text { тривожність }\end{array}$ & $\begin{array}{c}1,31 \pm \\
0,13 \\
\end{array}$ & $\begin{array}{c}0,98 \pm \\
0,07 \\
\end{array}$ & $\begin{array}{c}1,10 \pm \\
0,06 \\
\end{array}$ & $\begin{array}{c}0,24 \pm \\
0,01 \\
\end{array}$ & & $\begin{array}{c}\mathrm{P}^{3} \\
<0,001 \\
\end{array}$ & $\begin{array}{c}\mathrm{P}^{3} \\
<0,001 \\
\end{array}$ & $\begin{array}{c}\mathrm{P}^{3} \\
<0,001 \\
\end{array}$ \\
\hline $\begin{array}{c}\text { Шкала HOS } \\
\text { ворожість }\end{array}$ & $\begin{array}{c}1,46 \pm \\
0,15\end{array}$ & $\begin{array}{c}1,48 \pm \\
0,11\end{array}$ & $\begin{array}{c}1,47 \pm \\
0,08\end{array}$ & $\begin{array}{c}0,49 \pm \\
0,02\end{array}$ & & $\begin{array}{c}\mathrm{P}^{3} \\
<0,001\end{array}$ & $\begin{array}{c}\mathrm{P}^{3} \\
<0,001\end{array}$ & $\begin{array}{c}\mathrm{P}^{3} \\
<0,001\end{array}$ \\
\hline $\begin{array}{c}\text { Шкала РНОВ } \\
\text { фобії }\end{array}$ & $\begin{array}{c}0,89 \pm \\
0,13\end{array}$ & $\begin{array}{c}0,50 \pm \\
0,07\end{array}$ & $\begin{array}{c}0,65 \pm \\
0,06\end{array}$ & $\begin{array}{c}0,07 \pm \\
0,01\end{array}$ & $\begin{array}{c}\mathrm{P}^{1} \\
<0,05\end{array}$ & $\begin{array}{c}\mathrm{P}^{3} \\
<0,001\end{array}$ & $\begin{array}{c}\mathrm{P}^{3} \\
<0,001\end{array}$ & $\begin{array}{c}\mathrm{P}^{3} \\
<0,001\end{array}$ \\
\hline $\begin{array}{c}\text { Шкала PAR } \\
\text { паранояльність }\end{array}$ & $\begin{array}{c}1,41 \pm \\
0,13\end{array}$ & $\begin{array}{l}1,12 \\
0,07\end{array}$ & $\begin{array}{c}1,24 \pm \\
0,06\end{array}$ & $\begin{array}{c}0,39 \pm \\
0,01\end{array}$ & & $\begin{array}{c}\mathrm{P}^{3} \\
<0,001\end{array}$ & $\begin{array}{c}\mathrm{P}^{3} \\
<0,001\end{array}$ & $\begin{array}{c}\mathrm{P}^{3} \\
<0,001\end{array}$ \\
\hline $\begin{array}{c}\text { Шкала PSY } \\
\text { психотизм }\end{array}$ & $\begin{array}{c}0,87 \pm \\
0,10\end{array}$ & $\begin{array}{c}0,46 \pm \\
0,04\end{array}$ & $\begin{array}{c}0,62 \pm \\
0,04\end{array}$ & $\begin{array}{c}0,10 \pm \\
0,01\end{array}$ & $\begin{array}{c}\mathrm{P}^{2} \\
<0,01\end{array}$ & $\begin{array}{c}\mathrm{P}^{3} \\
<0,001\end{array}$ & $\begin{array}{c}\mathrm{P}^{3} \\
<0,001\end{array}$ & $\begin{array}{c}\mathrm{P}^{3} \\
<0,001\end{array}$ \\
\hline $\begin{array}{c}\text { Шкала ADD } \\
\text { додаткова }\end{array}$ & $\begin{array}{c}1,18 \pm \\
0,11\end{array}$ & $\begin{array}{c}0,94 \pm \\
0,07\end{array}$ & $\begin{array}{c}1,03 \pm \\
0,05\end{array}$ & $\begin{array}{c}0,36 \pm \\
0,01\end{array}$ & & $\begin{array}{c}\mathrm{P}^{3} \\
<0,001\end{array}$ & $\begin{array}{c}\mathrm{P}^{3} \\
<0,001\end{array}$ & $\begin{array}{c}\mathrm{P}^{3} \\
<0,001\end{array}$ \\
\hline $\begin{array}{c}\text { Індекс GSI } \\
\text { загальна виразність } \\
\text { психопатологічної } \\
\text { симптоматики }\end{array}$ & $\begin{array}{c}1,21 \pm \\
0,09\end{array}$ & $\begin{array}{c}0,92 \pm \\
0,04\end{array}$ & $\begin{array}{c}1,03 \pm \\
0,04\end{array}$ & $\begin{array}{c}0,32 \pm \\
0,01\end{array}$ & $\begin{array}{c}\mathrm{P}^{1} \\
<0,05\end{array}$ & $\begin{array}{c}\mathrm{P}^{3} \\
<0,001\end{array}$ & $\begin{array}{c}\mathrm{P}^{3} \\
<0,001\end{array}$ & $\begin{array}{c}\mathrm{P}^{3} \\
<0,001\end{array}$ \\
\hline
\end{tabular}

Примітка. Достовірність відмінностей між групами на рівні: $\mathrm{p}^{1}<0,05 ; \mathrm{p}^{2}<0,01 ; \mathrm{p}^{3}<0,001$

малою продуктивністю психічних процесів, зниженням пам'яті й інтелекту, нетриманням афектів. Формування патології особистості відбувається за астенічним, іпохондричним, паранояльним, психопатоподібним, істеричним, епілептоїдним типами.

Як видно з табл., виразність психопатологічної симптоматики GSI в групах обстежених нами бійців за всіма шкалами дослідження була достовірно вищою за контрольну групу $\left(\mathrm{p}^{1}<0,05\right.$; $\left.\mathrm{p}^{3}<0,001\right)$. Значення індексу виразності у бійців виявилося вищим майже в три рази, ніж у здорових $(1,03 \pm 0,04$ бала проти $0,32 \pm 0,01$ бала при $\left.\mathrm{p}^{3}<0,001\right)$, а в групі 39 бійців АТО із ЗГМЛС виразність психопатологічної симптоматики за шкалами була достовірно вищою, ніж у групі 61 бійця АТО із СГМ $(1,21 \pm 0,09$ бала проти $0,92 \pm 0,04$ бала при $\left.\mathrm{p}^{1}<0,05\right)$.

За допомогою визначення коефіцієнта кореляції нами були виявлені такі достовірні позитивні кореляційні зв'язки:
- в обох групах бійців АТО загальна виразність психопатологічної симптоматики GSI позитивно корелювала 3 усіма психопатологічними симптомами $(\mathrm{p}<0,05)$;

- у групі 39 вояків АТО із ЗГМЛС крім міцного кореляційного зв'язку загальної виразності психопатологічної симптоматики з усіма шкалами (GSI p<0,05), міжособистісна сенситивність INT мала міцний кореляційний зв'язок із депресією (DEP p $<0,05)$, обсесивністю - компульсивністю (ОС $\mathrm{p}<0,05)$, паранояльністю $(\mathrm{PAR} \mathrm{p}<0,05)$ та психотизмом (PSY $\mathrm{p}<0,05)$;

- обсесивність - компульсивність ОС позитивно корелювала $з$ депресією (DEP p $<0,05)$, тривожність ANX - із соматизацією (SOM $\mathrm{p}<0,05)$, а психотизм PSY- 3 паранояльністю (PAR p<0,05);

- у групі 61 бійця АТО із СГМ нарівні з виразністю кореляційних зв'язків загальної виразності психопатологічної симптоматики з усіма шкалами психопатологічних симптомів (GSI $\mathrm{p}<0,05)$, тривожність ANX мала міцний коре- 
ляційний зв'язок $з$ депресією (DEP $\mathrm{p}<0,05)$, паранояльність PAR позитивно корелювала 3 міжособистісною сенситивністю (INT p $<0,05$ );

- у групі контролю 73 здорових добровольців загальна виразність психопатологічної симптоматики GSI позитивно корелювала із соматизацією (SOM p<0,05), обсесивністю - компульсивністю (OC $\mathrm{p}<0,05)$, депресією (DEP $\mathrm{p}<0,05$ ), тривожністю (ANX $\mathrm{p}<0,05$ ), однак ми відзначили дещо слабші кореляційні зв'язки при фобіях PHOB із депресією (DEP p<0,05) i тривожністю (ANX p<0,05), а тривожності $\mathrm{ANX}$ - iз соматизацією (SOM $\mathrm{p}<0,05)$, обсесивністю - компульсивністю (ОС $\mathrm{p}<0,05)$ і депресією (DEP $\mathrm{p}<0,05)$.

Група із 39 бійців АТО із ЗГМЛС більш схильна до зміненої міжособистісної сенситивності, яка супроводжується депресією, обсесивністю компульсивністю, паранояльністю і психотизмом. У цій групі тривожність корелювала із соматизацією, психотизмом та паранояльністю, на відміну від групи із 61 бійця АТО із СГМ, де ми відзначили класичний кореляційний зв'язок тривожності з депресією.

Таким чином, 39 бійців АТО із ЗГМЛС потребують крім медикаментозної корекції проведення сеансів психотерапії, а вік у цій групі не мав достовірно значущих кореляційних зв'язків за шкалами психопатологічних симптомів. У групі 61 вояка АТО із СГМ проблемою була тривожність, яка корелювала із депресією, що потребувало лікування анксіолітиками та антидепресантами.У групі 73 добровольців мав місце позитивний кореляційний зв'язок зі шкалою соматизації.

\section{Висновки}

1. У бійців антитерористичної операції, які отримали закриту черепно-мозкову травму під час бойових дій, у віддаленому періоді має місце виражена психопатологічна симптоматика, ступінь якої зростає пропорційно до зростання тяжкості травми черепа і головного мозку.

2. У віддаленому періоді при струсі головного мозку у бійців антитерористичної операції переважають явища депресії, які потребують відповідної корекції антидепресантами.

3. У бійців із забоєм головного мозку легкого ступеня, окрім депресії мають місце явища психотизму та паранояльності, що вимагає застосування антидепресантів у поєднанні з активною психотерапевтичною корекцією їх стану.

4. У бійців антитерористичної операції, які отримали закриту черепно-мозкову травму до їх участі у воєнних діях, більш виражені явища соматизації, які потребують як психотерапевтичної, так і загальнотерапевтичної корекції.

Перспективи подальших досліджень. Наявність виражених психоемоційних змін у віддаленому періоді ЗЧМТ у бійців АТО ставить питання про створення спеціалізованих реабілітацій- них центрів, в яких протягом певного часу буде проводитись соціально-сімейна реабілітація таких хворих. Розробка основних напрямків роботи вказаних центрів та визначення термінів реабілітації потерпілих повинно стати завданням наших подальших досліджень.

\section{Література}

1. Гиляровский В.А. Отдаленные последствия закрытых травм головы в нервно - психической сфере / В.А. Гиляровский // Избранные труды. - М., 1973. C. $257-264$

2. Гублер Е.В. Вычислительные методы анализа и распознавание патологических процессов / Е.В. Гублер. М.: Медицина, 1978. - 294 с.

3. Лапач С.Н. Статистические методы в медико - биологических исследованиях с использованием Excel / Лапач С.Н., Губенко А.В., Бабич П.Н. - К.: Моріон, 2000. $-320 \mathrm{c}$

4. Невропатология контузионно - коммоционных повреждений мирного и военного времени / [М.М. Одинак, Н.В. Корнилов, А.И. Грицанов и др.]. - СПб.: MOPCAP, 2000. $-432 \mathrm{c}$

5. Посттравматичні стресові розлади: діагностика, лікування, реабілітація: методичні рекомендації / [П.В Волошин, Л.Ф. Шестопалова, В.С. Підкоритов та ін.] $-\mathrm{X} ., 2002 .-47 \mathrm{c}$.

6. Принципы оценки психопатологических синдромов при ЧМТ / [Зайцев О.С., Чебышева Л.Н., Ураков С.В., Засорина М.А.]: материалы ХІІ съезда психиатров России. - М., 1995. - С. 332-333.

7. Семчишин М.Г. Електроенцефалографічна характеристика черепно-мозкової травми легкого і середнього ступеня тяжкості в гострому і проміжному періодах / М.Г. Семчишин, Б.В. Задорожна // Клін. та експерим. патол. - 2015. - T. XIV, № 1 (51). - С. 139-142.

8. Семчишин М.Г. Мозковий кровотік при черепномозковій травмі легкого і середнього ступеня тяжкості в гострому та проміжному періодах згідно 3 даними ультразвукової доплерографії / М.Г. Семчишин, В.М. Шевага, Б.В. Задорожна // Бук. мед. вісник. 2015. - T. 19, № 1 (73). - C. 142-145.

9. Тарабрина Н.В. Практикум по психологии посттравматического стресса / Н.В. Тарабрина. - СПб.: Питер, 2001. $-272 \mathrm{c}$

10. Тарабрина Н.В. Психологические характеристики лиц, переживших военный стресс / Н.В. Тарабрина, Е.О. Лазебная, М.Е. Зеленова // Труды института психологии РАН. - М., 1997. - С. 254-262.

11. Тарабрина Н.В. Синдром посттравматических стрессовых нарушений: современное состояние и проблемы / Н.В. Тарабрина, Е.О. Лазебная // Психол. ж. 1992. - T. 13, № 2. - C. 14-29.

12. Bryant R.A. Acute stress disorder as a predictor of post traumatic stress disorder: a systematic review / R.A. Bryant // J. Clin. Psychiatry. - 2011. - Vol. 72. - P. 233-239.

13. Derogatis L.R. The SCL -90 and the MMPI: A step in the validation of a new self - report scale / L.R. Derogatis, K. Rickels, A. Rock // British J. of Psychiatry. - 1976. Vol. 128. - P. 280-289.

14. Head Injury - Pathophysiology and Management, $2^{\text {nd }}$ edition / P.L. Reilly, R. Bullock (eds). - Hodder Arnold: London, UK, 2005. $-501 \mathrm{p}$.

15. Horowitz M. J. Signs and symptoms of posttraumatic stress disorder / M.J. Horowitz, N. Wilner, N. Kaltreider // Archives of General Psychiatry. - 1980. - Vol. 37. P. 85-92.

16. Post - traumatic stress disorder: medicine and politics / D.J. Stein, S. Seedat, A. Iversen, S. Wessely // Lancet. 2007. - Vol. 369. - P. 139-144. 


\title{
ОСОБЕННОСТИ КЛИНИКИ И ТЕЧЕНИЯ ЗАКРЫТОЙ ЧЕРЕПНО-МОЗГОВОЙ ТРАВМЫ ЛЕГКОЙ СТЕПЕНИ ТЯЖЕСТИ У БОЙЦОВ АНТИТЕРРОРИСТИЧЕСКОЙ ОПЕРАЦИИ В ОТДАЛЕННОМ ПЕРИОДЕ
}

\author{
М.Г. Семчишин ${ }^{1}$ В.Н. Шевага ${ }^{2}$, Б.В. Задорожная ${ }^{2}$
}

Резюме. Статья посвящена изучению психопатологической симптоматики с помощью опросника DEROGATIS у бойцов антитеррористической операции (ATO) с закрытой черепно-мозговой травмой легкой степени тяжести в отдаленном периоде. Выявлена выраженность психопатологической симптоматики в группах обследованых нами бойцов по всем шкалам исследования была достоверно выше за контрольную группу. Дальнейшее изучение изменений в психологической сфере в отдаленном периоде закрытой черепно-мозговой травмы у бойцов АТО ставит вопрос о создании специализированных реабилитационных центров для проведения в них социальновосстановительной реабилитации таких пациентов.

Ключевые слова: закрытая черепно-мозговая травма, отдаленный период, антитеррористическая операция, психопатологические последствия.

\section{FEATURES OF THE CLINIC AND THE COURSE OF MILD CLOSED SKULL INJURY IN SOLDIERS OF ANTITERRORIST OPERATION IN REMOTE PERIOD}

\section{M.H. Semchyshyn ${ }^{1}$, V.M. Shevaga ${ }^{2}$, B.V.Zadorozhna ${ }^{2}$}

The purpose. To study the psychopathology consequences of the mild closed skull injury in soldiers of antiterrorist operation in remote period.

Methods. With the help a questionnaire symptom scales Derogatis the results were interpreted on three levels: common expression of psychopathology symptomatic, expression of individual scales, expression of individual symptoms.

Results. It was established that the expression of psychopathology symptomatic in the groups of soldiersthat we investigated by all scales of examination was reliable larger than in the control group. The index of severity of the soldiers appeared three times higher than in healthy volunteers. In the group of 39 men with brain contusion of mild severity the expression of psychopathology was observed on scales significantly higher than in the group of 61 fighters with brain concussion. With determination correlation coefficient we also found significant positive correlation of symptoms in study groups.

Conclusion. In soldiers of anti-terrorist operation against who had a closed head injury in the remote period there were severe psychotic symptoms, extent of which increased proportionally to the increasing severity of the injury. In men with brain concussion in the remote period dominated by the phenomenon of depression, requiring appropriate correction antidepressants. In men with brain contusion of mild severity occurred phenomenon of psychotism, paranoia, which required the use of antidepressants and psychological adjustment of their status. In the soldiers who received a closed head injury prior the operations against terrorism, a phenomenon expressed somatization, which required psychological and general-correction.

Key words: closed skull injury, remote period, antiterrorist operation, psychopathological consequences.

PAT "Ukrzaliznytsia", Lviv clinical hospital for railways (Lviv) ${ }^{1}$, Danylo Halytskyi National Medical University (Lviv) ${ }^{2}$

Рецензент - проф. В.М. Пашковський
Buk. Med. Herald. - 2016. - Vol. 20, № 3 (79). - P. 171-174

Надійшла до редакції 27.06.2016 року

(C) М.Г. Семчишин, В.М. Шевага, Б.В. Задорожна, 2016 